\title{
Assessment in Science Learning Based on Ethnoscience
}

\author{
Hikmawati1 $^{*}$, I Wayan Suastra ${ }^{2}$ A.A. Istri Agung Rai Sudiatmika² \\ ${ }^{1}$ Department of Physics Education, Universitas of Mataram, Mataram, Indonesia. \\ 2 Education Science Doctoral Study Program, Universitas Pendidikan Ganesha, Bali, Indonesia.
}

\section{DOI: $10.29303 /$ jppipa.v7i3.736}

\section{Article Info}

Received: May 10th 2021

Revised: July 5th 2021

Accepted: July 13th, 2021

\begin{abstract}
This study aims to describe the assessment of ethnoscience-based science learning. The research data were collected through field observations and literature review. The research data were analysed descriptively. The results showed that: 1) there are five learning dimensions associated with ethnoscience-based assessment in science learning; 2) there are six dimensions of science related to ethnoscience-based assessment in science learning; 3) the type of assessment in ethnoscience-based science learning, divided based on the types of tests and non-tests; 4) construction of ethnoscience-based learning outcomes tests can be made from understanding to higher order thinking (HOT); 5) The ethnoscience-based essay test includes story questions about Sasak Sade Village, Bau Nyale Tradition, Sesek Weaving, Gendang Beleq, and Poteng Reket.
\end{abstract}

Keywords: assessment; science learning; ethnoscience.

Citation: Hikmawati, H., Suastra, I., \& Sudiatmika, A. (2021). Assessment in Science Learning Based on Ethnoscience. Jurnal Penelitian Pendidikan IPA, 7(3), 443-451. doi:https:// doi.org/10.29303/jppipa.v7i3.736

\section{Introduction}

Assessment is closely related to testing, measurement and evaluation. Assessment is an activity to interpret the measurement results and synthesize the results into new numbers or alphabets or categorization. Testing is the process of implementing tests, to determine the level of ability (knowledge, attitudes, and skills) of a person. Testing is related to the timing of the test (during the test). The test is defined as a tool or instrument of measurement used to obtain data about a specific characteristic or feature of an individual or group. The test as a data collection instrument is a series of questions or exercises that are used to measure the knowledge skills, intelligence, abilities or talents of an individual or group. Teste is the respondent who takes the test, while the tester is someone who is assigned the task of carrying out the test to the respondent. Measurement is the activity of measuring an attribute or object using an instrument that has a consistent measurement scale in the form of numbers. Evaluate is an activity to collect information about the work of something, which is then used to determine the right alternative in making decisions. Thus, evaluation (to make decisions) can be carried out after the implementation of testing (using both tests and nontests), measurement (comparing using certain instruments), and assessment (interpreting the measurement results). In other words, Gabel (1993) states that evaluation is a process of assessing data or results obtained through assessment. The relationship between assessment, evaluation, measurement, and testing can be illustrated in Figure 1.

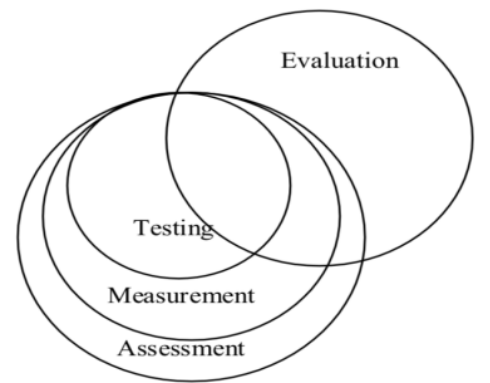

Figure 1. The relationship between assessment, evaluation, measurement, and testing

Evaluation is an important component and a stage that must be taken by the teacher to determine the effectiveness of learning. The results obtained from the 
evaluation can be used as a consideration for teachers in improving and perfecting learning programs and activities. The terms used in the evaluation system, namely measurement, assessment and evaluation. In learning activities, evaluation is preceded by an assessment, while assessment is preceded by measurement. In the measurement, the activity is carried out to compare the results of the observations with the criteria. Then, the measurement results are interpreted and described in the assessment process. Furthermore, evaluation, namely determining the value or implication of behaviour The types of instruments used in the assessment are test and non-test. The steps in analysing the non-test results are: transferring the qualitative data from the questionnaire results into quantitative data and comparing the total score (mean score) of each student with the total score of neutral (mean score is neutral). On the other hand, the steps used to analyse test results, namely: scoring and interpreting test scores (Zainal, 2020).

Figure 2 provides an illustration of a congruent triangle in which the standard curriculum, learning program, and assessment (evaluation system) interact in the planning and implementation of a successful science program. If one of the three dimensions is not clearly related or related to other dimensions, it will affect the fairness, credibility, validity, and usefulness of the assessment (Reynolds, et al., 1996 in Doran, et al., 2002).

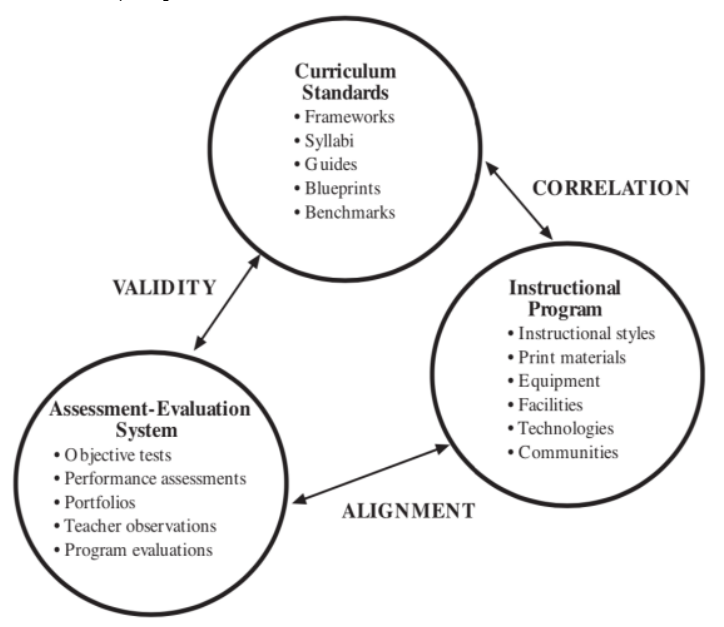

Figure 2. Congruence Triangle

The principal plays an important role in the evaluation system in schools. Marshall (2009) states four closely related strategies for principals: conducting brief unannounced class visits followed by one-on-one feedback conversations; participate much more actively in the curriculum planning process; work with a team of teachers to analysed and follow up on the results of interim assessments; and using a rubric for year-end teacher evaluations. It is the most effective way for principals to exercise instructional leadership and make a real difference at the classroom level. Figure 3 is a diagram showing how the four strategies interact. The implementation of these four strategies involves fundamental changes in the way principals handle supervision and evaluation as well as professional dynamics in schools.

\section{The Four-Part Strategy for Improving Teaching and Learning: Basic Elements}

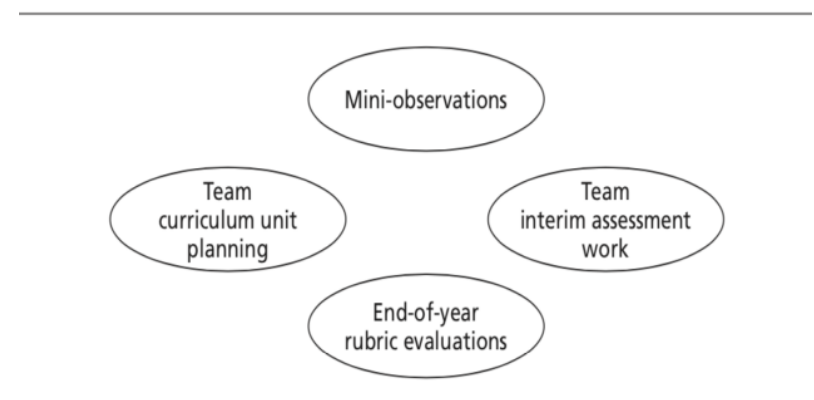

$\overline{\text { Figure 3. The principal's four strategies for improving the }}$ quality of learning

The assessment produces a very comprehensive picture of students' abilities. For this reason, teacher preventive measures greatly help students improve achievement. Therefore a teacher should be able to pick up on signs of whether the observed student understands, is confused or unprepared, and so on. Eye gaze, hand movements, body movements, leg movements and so on can provide very informative cues. These signs when observed can provide very important information about student learning development, student learning difficulties, and student learning patterns (Mansur, 2018).

A good assessment model will pay attention to the nature of science, the nature of scientific literacy, and the nature of the assessment. The assessment of science process skills focuses on intellectual or reasoning aspects in the form of paper and pencil test sets, and in the form of performance assessments (assignments and rubrics) is an assessment model that is in accordance with student skills expected in the 21st century (Rustaman, 2017).

According to Magnusson, et al. (1999), the pedagogical content knowledge component suggests the importance of including the following elements in science teacher education programs: Science education goals and their relationship to science teaching objectives (knowledge of science teaching orientation, knowledge of science goals and objectives); Instructional strategies appropriate to a specific orientation for teaching science (knowledge of subject-specific strategies, specific science curriculum knowledge); Planning, implementing, and reflecting on the teaching of specific science topics, guided by consideration of student understanding (student understanding knowledge, science assessment knowledge), and 
appropriateness/value of using specific instructional strategies (knowledge of specific topic strategies); Assessment planning and administration compatible with one's orientation to science teaching and its targeted goals (science assessment knowledge).

To teach science well, science teachers need to know what to focus on to ensure their assessment of student learning is meaningful and useful for ongoing student learning and development. The diversity and variety of content and skills in science subjects means that the assessment skills needed by science teachers are very broad and complex, requiring specific knowledge and skills in the assessment of science learning as part of teachers' pedagogical content knowledge (Edwards, 2013).

This paper will describe the assessment of ethnoscience-based science learning, including: 1) learning dimensions related to assessment in ethnoscience-based science learning; 2) The scientific dimension related to assessment in science learning based on ethnoscience; 3) The type of assessment in science learning based on ethnoscience; 4) Construction of ethnoscience-based learning outcomes tests; 5) Examples of ethnoscience-based learning outcomes tests.

\section{Method}

This research is a needs analysis research which will be used as the basis for designing an assessment model in ethnoscience-based science learning. The data collected in this study include:

1) Learning dimensions related to assessment in ethnoscience-based science learning;

2) The scientific dimension related to assessment in science learning based on ethnoscience;

3) The type of assessment in science learning based on ethnoscience;

4) Construction of ethnoscience-based learning outcomes tests;

5) Examples of ethnoscience-based essay tests include story questions about Sasak Sade Village, Bau Nyale Tradition, Sesek Weaving, Gendang Beleq, and Poteng Reket.

This research data was collected through field observations and literature review. The research data were then analysed descriptively.

\section{Result and Discussion}

Learning dimensions related to assessment in ethnoscience-based science learning
Marzano, et al. (1993) stated that there are five dimensions of learning, namely as follows:

1) Positive Attitudes and Perceptions About Learning

Without positive attitudes and perceptions, students have few opportunities to learn proficiently. In other words, in order for learning to occur, students must have certain attitudes and perceptions. Feeling comfortable in class, for example, is important for studying. If a student does not believe that the classroom is safe and an orderly place, he or she may study a little in that class. Likewise, if he doesn't have a positive attitude about classwork, he probably won't try hard to do it and, again, the learning won't be fun. The main focus of effective learning is to build positive attitudes and perceptions about learning.

2) Acquiring and Integrating Knowledge

Helping students acquire new knowledge, integrate it with what they already know, and retain it are important aspects of learning. When there is new knowledge/material, teacher planning should focus on strategies that will help students relate new knowledge to previous knowledge, organize new knowledge in a meaningful way, and make it part of their long-term memory. For example, a teacher could help students relate what new information they learned to what they already know by helping them create analogies for new information. The teacher may be able to suggest that they make an outline or a graphical representation of the new information. The teacher may be able to help students more effectively retain information in longterm memory by guiding them through making pictures that represent important aspects of the new information/knowledge.

3) Expanding and Improving Knowledge

Acquiring and integrating knowledge is not the end of the learning process. Learners expand and refine their knowledge, add new differences and make further connections. They analysed what they had learned in greater depth and more thoroughly. While expanding and refining their knowledge, learners usually engage in the following activities: Comparing; Classify; Make induction; Make deductions; Analyze errors; Create and analyze findings; Analyze information; Summarize.

4) Using Knowledge Meaningful

Cognitive psychologists argue that effective learning occurs when students are able to use knowledge to perform meaningful tasks. Teachers can plan lessons so that students have the opportunity to use meaningful knowledge is one of the most important decisions a teacher can make. In the Dimensions of the Learning model there are five types of tasks that encourage the use of meaningful knowledge: decision making; investigation; experimental inquiry; problem solving; invention.

5) Productive Thinking Habits 
The last aspect of learning is perhaps the most important. This concerns the use of habits of productive thought patterns such as critical thinking, creative thinking, and self-regulating thinkers. Although acquiring new knowledge is important, it may not be the most important goal of education. Ultimately, developing mental habits that will allow individuals to learn for themselves whatever they want or need to know at any time in their life is perhaps the most important goal of education. Some of these productive thinking habits include: Being clear and seeking clarity; Being open-minded; Restraining impulsivity; Being aware of your own thinking; Evaluating the effectiveness of one's own actions; Push the limits of one's own knowledge and abilities; Engage intensely in a task even when the answer or solution is not immediately apparent. The learning dimensions can be described in a diagram like the following.

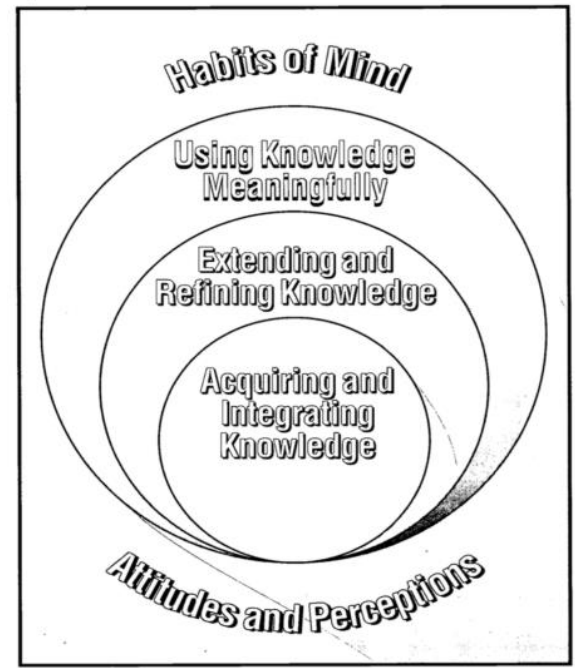

Figure 4. Dimensions of learning

Habits of mind is one of the dimensions of longterm learning outcomes consisting of critical thinking, creative thinking, and self-regulation. For this reason, it needs to be developed for the character of the nation (Susilowati, et al., 2018).

The scientific dimension related to assessment in science learning based on ethnoscience

Enger \& Yager (2009) stated that there are 6 dimensions of science in relation to assessment which can be described as follows.

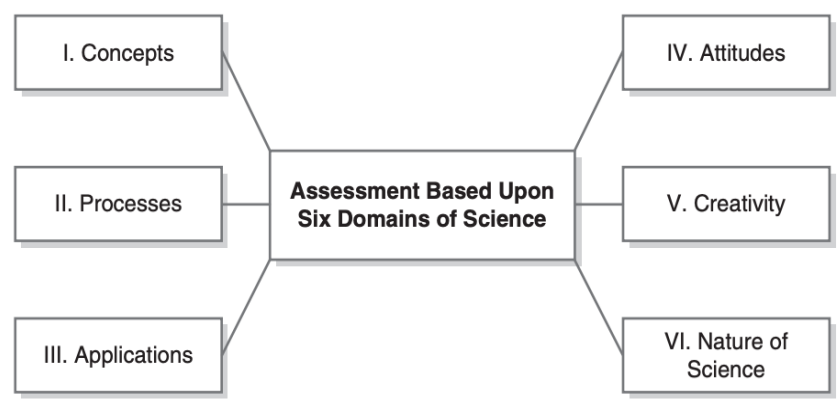

Figure 5. Dimensions of science

The characteristics of the 6 dimensions of science can be seen in table 1 below:

Table 1. Characteristics of the 6 dimensions of science Science Domain

Domain Foci

I. Concepts (knowing and understanding)

Scientific information-facts, concepts, laws, hypotheses, and theories accepted by the scientific community

II. Processes (exploring and discovering)

III. Aplications (using and applying)

Processes of science, how scientifics work and think

Aplication of what is learned di science, connections to everyday life; informed decision making

IV. Attitudes (feeling and aluing)

V. Creativity (imagining Idea generation, designing, and creating)

VI. Nature of Science (the scientific endeavor) problem solving History and philosophy of science; how science progresses and science knowledge and understanding develop

\section{Types of assessment in science learning based on ethnoscience}

According to Sahidu (2013), the test instrument in assessment is a set of tools that aims to measure the achievement of the learning competencies that have been planned. Test instruments to measure student learning outcomes include objective tests (multiple choice, short answer, matchmaking, true-false), test descriptions, performance performance and portfolios. The form of the non-test instrument consisted of interviews, inventories, and observations.

Sahidu (2013) further explains that assessment other than tests is related to affective aspects which are part of learning outcomes and have an important role. There are 4 types of important affective characteristics, namely: attitudes, interests, self-concept, and values. Attitude is a positive or negative feeling towards an object (subject). Usually the data is taken by means of a questionnaire. Attitude indicators towards science subjects, for example: reading books, interacting with teachers, doing assignments, discussing science 
material. Interest is the student's curiosity about the state of an object (subject). Indicators of interest in science, for example: the benefits of learning science, efforts to understand science, asking questions in class about science, reading science books. Self-concept is a statement about one's own abilities concerning the subject. Indicators such as: 1) self-strength in both cognitive, psychomotor and affective aspects; 2) lessons that are found difficult; 3) easy lessons. Value is a person's belief about the state of an object or activity. Indicators such as: beliefs about student achievement, student success, expectations of parents, community support, the role of the school.

Alternative assessments in science are openended questions, performance-based tasks, expanded multiple-choice questions, holistic assessments, and questions that assess the ability to solve problems, apply key principles, and integrate concepts (Herr, et al., 1995).

The test writer focuses on content validity, reliability, difficulty level and discrimination index, all of which are essential for the development of highquality tests. Many tests, such as the Science Processes Skills (SPS) which are widely used in the literature have been developed to meet this requirement. However, due to the nature of SPS, if multiple choice questions are to be used, scenarios must be carefully formulated in question stems. For example, when writing questions, multi-stage experimental scenarios need to be considered. In a multiple-choice SPS test, the question writer generally asks students to determine what hypothesis is being tested in an experiment and to identify variables in a one-stage experiment. But in science, an experiment can have several stages, and different hypotheses can be tested in each section. Therefore, the variables that are manipulated in the first part of the experiment can become the controlled variables in the second. If a student chooses the correct answer in a multiple choice test, this is still not enough to conclude that the student's knowledge of the subject is complete and accurate. In addition, a student may choose a distraction as the correct answer due to lack of information and mistakes made during the exam. In order for a student to be considered successful in a skill, he must be able to correctly answer two parts of the related scenario (Temiz, 2020).

Students who are oriented towards the procedures used, can be in the form of rubrics used in assessing their performance such as preparing equipment, following procedures, data collection, safety and cleaning procedures. A student-centered approach that undertakes hands-on activities that combine inquiry-based science teaching into science teaching has significantly improved students' science process skills (Balanay, 2013).
Therefore, assessment for learning, including in science learning, has many common features but there are several features of Assessment for Learning (AfL) that can be specifically honed for science teaching and learning. The classroom climate is so important, that a co-constructivist, non-threatening environment is created in order for students to feel capable of expressing their ideas and allows teachers to establish what students know, what they don't know and what they do partially know and to develop effective teaching. will move their understanding. Assessment for Learning has been defined as: The process of seeking and interpreting evidence for use by students and their teachers to decide where learners are in their learning, where they should go and the best way to get there. Thus, the teacher must understand the answers to several questions, namely: What involves AfL in science? What are the most commonly used AfL techniques in science? Does science use a different AfL technique for other subjects? How often is AfL used in science? (Hodgson \& Pyle, 2010).

Thus, assessment has an important role in education and has an important role in the teaching process. Through proper assessment, teachers can classify and rate their students, provide feedback, and structure their teaching accordingly (Tosuncuoglu, 2018).

\section{Construction of ethnoscience-based learning outcomes tests}

According to Sahidu (2013), the preparation of a learning outcome test as an instrument must meet validity and reliability requirements. In developing an assessment instrument, steps are needed, namely: compiling a grid, developing instrument items, reviewing and revising instrument items, testing instruments, empirical analysis of instrument quality. According to Trianto (2008), learning outcomes tests are made referring to the basic competencies to be achieved, translated into indicators of achievement of learning outcomes, and arranged on a grid of writing questions equipped with answer keys. According to Uslan, et al. (2018), the stages of developing a project learning assessment tool include: definition (preliminary and final analysis, student analysis, material analysis, and assessment analysis), design (preparation of assessment designs, media selection, format selection, and initial design), development, and dissemination.

The design of the diagnostic assessment can be in the form of tests and interviews, the results of diagnostic assessments in the form of information related to student weaknesses are used as a basis for compiling learning that can help students better understand the material according to their respective conditions, and support the achievement of learning objectives (Firmanzah \& Sudibyo, 2021 ). In other words, good 
learning tools (including test instruments or evaluation tools) will create a quality learning process (Utami, et al., 2019).

According to Ramdani, et al. (2019), in the aspect of the evaluation tool developed by the teacher, some important information can be seen, including that the instrument developed meets the principles of assessment, its presentation is in accordance with the rules of the curriculum, as well as consideration of the suitability of the indicators of achieving the expected competencies and the instruments used. . In this aspect, in general, the question document prepared by the teacher only measures LOTS, some of which are almost at the HOTS measurement level. The aspects that are assessed in the Learning Outcomes Evaluation Tool are: 1) Fulfilling the basic principles of assessment; 2) Items can measure skills or life skills according to the abilities expected by 21st century learning (HOTS); 3) The language used is good and correct; 4) Consideration of the distribution of questions, time allocation.

All teachers should be encouraged and motivated to introduce new features and improvements to their work, including in terms of evaluation and assessment, so that students can demonstrate their knowledge in different ways and in authentic problem situations. Teachers should be given the opportunity for further education, supported by professionals and high-quality professional literature, from which to draw ideas for their work (Hus \& Matjašič, 2017).

Analysis of the quality of the test equipment is a crucial thing that needs to be done. The test instrument made by the teacher must meet the requirements (validity, reliability, and standard error of measurement) so that the measurement results obtained can describe the actual abilities of students. The teacher's ability to make final exam test instruments for the semester is still limited. This is proven as a problem found through the representation of the results of the analysis based on the content validity test, empirical validation, reliability and standard error of measurement. It is recommended that the principal or the Education Office regularly conduct effective training and invite teachers to participate in it in order to hone their skills in making effective test instruments (Ramadhan, et al., 2020).

Science education is facing dramatic changes, so a new framework is needed designed to guide educators in significantly changing the way science is taught - from kindergarten to high school. This framework aims to make science education more like the way scientists work and think. It also aims to make instruction reflect research on learning that shows the importance of building a coherent understanding over time. The framework organizes science learning around three dimensions: core ideas from the disciplines of life, physics, earth and space sciences, and engineering and technology; the practices scientists and engineers use to do their jobs; and key cross-cutting concepts linking disciplines. This means that they must be interwoven in every aspect of science education, most critically, curriculum, teaching and assessment. The framework emphasizes the importance of relationships between core ideas of scientific disciplines, such as using an understanding of chemical interactions from physical science to explain biological phenomena (Pellegrino, et al., 2013).

There is general agreement that what is being assessed influences the priority given by the teacher for the various learning objectives and it is therefore important that all important objectives are included in what is being assessed. It is suggested that this will be facilitated if the curriculum and assessment are developed jointly by the same institution, to avoid being effectively transformed into a series of unrelated tasks inspiring goals. A related thing made by several participants was that the assessment must be in line with the learning theory that underlies Inquiry-Based Science Education (IBSE). There is a strong opinion that the relationship between good judgment, the application of IBSE and the development of key scientific ideas needs to be elaborated. A description of what is meant by 'quality' in science learning and how this differs at different ages as students progress in 'science' and 'about science' learning. Assessment should support, and be seen to support, the development of good student character and the knowledge and skills needed to address major global problems. Education policies based on ambitions for high-level performance in international examinations and surveys need to be aligned with concerns for high-quality education for all (Harlen, 2013).

\section{Examples of ethnoscience-based learning outcomes tests}

Local wisdom on Lombok Island that has ethnoscience potential are Sasak Sade Village, Bau Nyale Tradition, Sesek Weaving, Gendang Beleq, and Poteng Reket (Hikmawati, et al, 2021). Learning materials in accordance with ethnoscience can be shown in Table 2.

Table 2. Local wisdom that has ethnoscience potential

\begin{tabular}{lll}
\hline Ethnoscience & Basic competencies & $\begin{array}{l}\text { Learning } \\
\text { materials }\end{array}$ \\
\hline $\begin{array}{l}\text { Sasak Sade } \\
\text { Village }\end{array}$ & $\begin{array}{l}\text { Apply the concept } \\
\text { measurement of } \\
\text { various quantities } \\
\text { using standard units }\end{array}$ & Measurement \\
& $\begin{array}{l}\text { (standard) } \\
\text { Classify living things } \\
\text { and objects based on } \\
\text { Bau Nyserved lavification } \\
\text { Tradition }\end{array}$ & \\
& characteristics & \\
\hline
\end{tabular}




\begin{tabular}{|c|c|c|}
\hline Ethnoscience & Basic competencies & $\begin{array}{l}\text { Learning } \\
\text { materials }\end{array}$ \\
\hline $\begin{array}{l}\text { Sesek } \\
\text { Weaving }\end{array}$ & $\begin{array}{l}\text { Explain the concept of } \\
\text { mixtures and } \\
\text { substances } \\
\text { single (elements and } \\
\text { compounds), physical } \\
\text { and chemical } \\
\text { properties, physical } \\
\text { and chemical changes } \\
\text { in everyday life }\end{array}$ & $\begin{array}{l}\text { Substance and } \\
\text { Characteristics }\end{array}$ \\
\hline $\begin{array}{l}\text { Gendang } \\
\text { Beleq }\end{array}$ & $\begin{array}{l}\text { Analyzing the } \\
\text { concept of vibration, } \\
\text { waves, and sounds, in } \\
\text { everyday life, } \\
\text { including the human } \\
\text { auditory system and } \\
\text { the sonar system in } \\
\text { animals }\end{array}$ & $\begin{array}{l}\text { Vibrations, } \\
\text { Waves and } \\
\text { Sounds }\end{array}$ \\
\hline Poteng Reket & $\begin{array}{l}\text { Apply the concept of } \\
\text { biotechnology and } \\
\text { role in human life }\end{array}$ & $\begin{array}{l}\text { Biotechnology } \\
\text { and Food } \\
\text { Production }\end{array}$ \\
\hline
\end{tabular}

The assessment for each local wisdom that has ethnoscience potential is as follows:

1) Sasak Sade Village

The Sasak tribe community in Sasak Sade Village has a non-standard unit of measure in measuring traditional house buildings, namely: the width is called sesata (the distance from the tip of the middle finger to the elbow of the hand), the length is called sedepa (the distance from the tip of the middle finger of the right arm to the tip of the finger. the middle of the left arm is stretched out), and the height is called a sprunjung (the distance from the sole of the foot to the tip of the middle finger of the hand). The following is data on the results of table measurements made by 4 people using non-standard units (sesata) and standard units $(\mathrm{cm})$ :

Table 3. Measurement data using standard and nonstandard units

\begin{tabular}{llll}
\hline $\begin{array}{l}\text { Measure } \\
\text { name } \\
\text { (Person) }\end{array}$ & $\begin{array}{l}\text { Table } \\
\text { length } \\
\text { (sesata) }\end{array}$ & $\begin{array}{l}\text { Measure } \\
\text { name } \\
\text { (Measuring } \\
\text { instrument) }\end{array}$ & $\begin{array}{l}\text { Table length } \\
(\mathrm{cm})\end{array}$ \\
\hline Buyung & 3.00 & Plastic ruler & 140 \\
Wati & 3.50 & Metal ruler & 140 \\
Atir & 4.00 & Elbow ruler & 140 \\
Rido & 4.50 & Roll ruler & 140 \\
\hline
\end{tabular}

Answer the following questions based on the observed data table: (a) Are the results of the measurement of the length of the table made by different people based on sesata units? (b) Can the sesata units be used as standard units? (c) Explain the sesata unit shortage! (d) Are the results of all table length measurements using different measuring instruments? (e) Describe excess $\mathrm{cm}$ as the unit of measurement for length! (f) Bau Nyale Tradition

The Bau Nyale tradition is a tradition of the Sasak tribe to hunt sea worms on the beach which is believed to be the incarnation of Princess Mandalika. The sea worm (Nyale) has the Latin name Eunice viridis, including the type of filumannelida and classified in the kingdom Animalia. Explain the characteristics of Nyale in terms of the groupings of living things that belong to the kingdom Animalia!

\section{2) Sesek Weaving}

The name sesek is taken from the origin of the sound when weaving "sek sek". The yarn dyes used are made from plant materials, and produce the various colors needed to make the motifs the weavers desire. Coloring materials such as jackfruit or mahogany bark, fruit skin with mangosteen or mangosteen can be used repeatedly by boiling. If these materials can no longer give color, burned for cooking purposes, the ashes can be used to clean moss and wash kitchen utensils. The paste made from tarum leaf deposits produces an indigo blue color. To produce black color, it requires a long coloring process because the yarn has to be dipped in indigo solution and cured in the ground repeatedly to get the desired color. After the soaking process, the tarum twigs and leaves can be drained and then burned. The ashes from the tarum twigs and leaves are used as natural fertilizer in the fields and become a dye mixture when dyeing the threads. Based on the description above, explain the difference between a physical change and a chemical change!

\section{3) Gendang Beleq}

In ancient times the Sasak people beat Gendang Beleq with the aim of arousing the spirit of the community when going to war. However, with the times the Gendang Beleq was used to accompany the bride and groom and to entertain guests who came to weddings and important events held on the island of Lombok. What are the conditions for hearing the sounds emitted by the traditional Gendang Beleq musical instruments? How is the process of hearing the sound emitted by the traditional Gendang Beleq musical instruments until finally it is heard by the ear?

\section{4) Poteng Reket}

Poteng Reket is a traditional Sasak snack, usually only available during certain celebrations such as traditional celebrations or Eid al-Fitr or Eid al-Adha. Poteng Reket is made from steamed sticky rice without coconut, the manufacturing process is not much different from jaje tujak (pounded snack), there are only a few different processes, this poteng itself is not made like mashed jaje tujak, only after steaming the sticky rice. 
chilled and given yeast or mixed with tape and let stand for about 2 days. What is meant by the fermentation process in conventional biotechnology so that it can be useful in producing food products in the form of poteng reket? Explain the factors that influence the success of the fermentation!

\section{Conclusion}

Five dimensions of learning related to assessment in ethnoscience-based science learning consist of; positive attitudes and perceptions about learning, acquiring and integrating knowledge, expanding and improving knowledge, using meaningful knowledge, productive thinking habits. Six dimensions of science related to assessment in ethnoscience-based science learning are; concepts, processes, applications, attitudes, creativity, nature of science. The construction of ethnoscience-based learning outcomes tests can be made from understanding to higher-order thinking that must meet validity and reliability requirements. The test is made referring to the basic competencies to be achieved, translated into indicators of achievement of learning outcomes, and arranged based on a grid of writing questions equipped with answer keys. Examples of ethnoscience-based essay tests can be in the form of story questions about local wisdom on the island of Lombok, such as: Sasak Sade Village, Bau Nyale Tradition, Sesek Weaving, Gendang Beleq, and Poteng Reket.

\section{References}

Balanay, C.,A.,S. (2013). Assessment on Students' Science Process Skills: A Student- Centred Approach. International Journal of Biology Education, 3 (1), 24-44. Retrieved from: www.ijobed.com

Doran, R., Chan, F., Tamir, P., \& Lenhardt, C. (2002). Science Educator's Guide to Laboratory Assessment. National Science Teachers Association (NSTA) Press: Virginia. Retrieved from: www.nsta.org

Edwards, F. (2013). Quality assessment by science teachers: Five focus areas. Science Education International, 24 (2), 212-226.

Enger, S., K. \& Yager, R., E. (2009). Assessing Student Understanding in Science. California: Corwin Press Inc.

Firmanzah, D. \& Sudibyo, E. (2021). Implementasi Asesmen Diagnostik Dalam Pembelajaran IPA Pada Masa Pandemi COVID-19 Di SMP/MTs Wilayah Menganti, Gresik. Pensa E-Jurnal: Pendidikan Sains, 9 (2), 165-170. [Indonesian]
Gabel, D.L. (1993). Handbook of Research on Science Teaching and Learning. New York: Macmillan Company.

Harlen, W. (2013). Assessment \& Inquiry-Based Science Education: Issues in Policy and Practice. Trieste, Italy: the Global Network of Science Academies (IAP) Science Education Programme (SEP). Retrieved from: www.interacademies.net/activities/projects/122 50.aspx

Herr, N., Holzer, M., Martin, M., Esterle, R., \& Sparks, C. (1995). Preparing Student Teachers for Alternative Assessment in Science. Journal of ScienceTeacherEducation, 6 (1), 27-32.

Hikmawati, Suastra, I, W. \& Pujani, N., M. (2021). Local wisdom in Lombok island with the potential of ethnoscience for the development of learning models in junior high school. Journal of Physics: Conference Series, 1816 (2021) 012105. doi: 10.1088/1742-6596/1816/1/012105.

Hodgson, C. \& Pyle, K. (2010). A literature review of Assessment for Learning in science. National Foundation for Educational Research (NFER). Retrieved from: www.nfer.ac.uk

Hus, V. \& Matjasǐc, J. (2017). Evaluation and Assessment in Early Social Science. Universal Journal of Educational Research, 5 (4): 664-670. DOI: 10.13189/ujer.2017.050415.

Magnusson, S. J., Borko, H., \& Krajcik, J. S. (1999). Nature, sources, and development of pedagogical content knowledge for science teaching. In J. GessNewsome \& N. Lederman (Eds.), Examining Pedagogical content Knowledge (pp. 95-132). Boston, MA: Kluwer Press.

Mansur, S. (2018). Aplikasi Asesmen Dalam Pembelajaran IPA Di Kelas IV Sekolah Dasar Negeri Gelogor. Jurnal Riset Pendidikan Dasar, 01 (1), 49-55. [Indonesian]

Marshall, K. (2009). Rethinking Teacher Supervision and Evaluation: How To Work Smart, Build Collaboration, And Close The Achievement Gap. San Francisco: Jossey-Bass. Retrieved from: www.josseybass.com

Marzano, R. J., Pickering, D. \& McTighe, J. (1993). Assessing Student Outcomes: Performance Assessment Using the Dimensions of Learning Model. Alexandria, Virginia, USA: Association for Supervision and Curriculum Development.

Pellegrino, J., W., Wilson, M., R., Koenig, J., A. \& Beatty, A., S. (2013). Developing Assessments for the Next Generation Science Standards. Washingyon, D.C.: National Academy of Sciences. www.nap.edu

Ramdani, A., Jufri, A., W., Gunawan, Hadisaputra, S., Zulkifli, L. (2019). Pengembangan Alat Evaluasi Pembelajaran IPA Yang Mendukung 
Keterampilan Abad 21. Jurnal Penelitian Pendidikan IPA (JPPIPA), 5 (1), 98-108. DOI: 10.29303/jppipa.v5i1.221 [Indonesian]

Ramadhan, S., Sumiharsono, R., Mardapi, D., \& Prasetyo, Z. K. (2020). The Quality of Test Instruments Constructed by Teachers in Bima Regency, Indonesia: Document Analysis. International Journal of Instruction, 13 (2), 507-518. https://doi.org/10.29333/iji.2020.13235a

Rustaman, N., Y. (2017). Assessment in Science Education. IOP Conf. Series: Journal of Physics: Conf. Series, 1829354(526071879)012141. doi: 10.1088/1742-6596/895/1/012141.

Sahidu, C. (2013). Penilaian Hasil Belajar. Lombok Barat: Arga Puji Press. [Indonesian]

Susilowati, E., Hartini, S., Suyidno, T Mayasari, T., \& Winarno, N. (2018). Profile Habits of Mind Students inPhysics Learning. IOP Conf. Series: Journal of Physics: Conf. Series, 1120 012055. doi: 10.1088/1742-6596/1120/1/012055.

Temiz, B., K. (2020). Assessing Skills of Identifying Variables and Formulating Hypotheses Using Scenario-Based Multiple-Choice Questions. International Journal of Assessment Tools in Education, $\quad 7 \quad$ (1), $1-17$. https://dx.doi.org/10.21449/ijate.561895

Tosuncuoglu, I. (2018). Importance of Assessment in ELT. Journal of Education and Training Studies, 6 (9), 163-167. doi:10.11114/jets.v6i9.3443

Uslan, Ivo, B. K., \& Abdul, S., M. (2018). Pengembangan Perangkat Asesmen Pembelajaran Proyek Pada Materi Perkembangbiakan Tumbuhan. Jurnal Ilmiah Profesi Pendidikan, 3 (1), 79-84. [Indonesian]

Utami, S., D., Efendi, I., Dewi, I., N., Ramdani, A., Rohyani, I., S. (2019). Validitas Perangkat Pembelajaran Etnoekologi Masyarakat Suku Sasak Kawasan Taman Nasional Gunung Rinjani. Jurnal Penelitian Pendidikan IPA (JPPIPA), 5 (2), 240-247, DOI: $\quad 10.29303 /$ jppipa.v5i2.291 [Indonesian]

Zainal, N., F. (2020). Pengukuran, Assessment dan Evaluasi dalam Pembelajaran Matematika. LAPLACE : Jurnal Pendidikan Matematika, 3 (1), 826. https://doi.org/10.31537/laplace.v3i1.310 [Indonesian] 